\title{
KARAKTERISTIK DAN PENERAPAN ISLAMIC CORPORATE GOVERNANCE PADA PERBANKAN SYARIAH
}

\author{
Fadiyah Hani Sabila
}

Universitas Padjadjaran,fadiyahhanis@gmail.com

\author{
Diterima: 3 Maret 2018 \\ Direvisi: 27 Oktober 2018 \\ Diterbitkan: 30 Desember 2018
}

\begin{abstract}
As one of the business entities under the umbrella of the unitary state of Indonesia, Islamic banks are also required to implement Good Corporate Governance which will henceforth be abbreviated as GCG. The application of GCG in Islamic banks is important considering Islamic banks are banks that use the principle of profit sharing. GCG is a requirement for Islamic banks to develop well and healthy. Good GCG implementation refers to five principles, namely accountability, transparency, independence, responsibility and fairness. The concept of Good Corporate Governance between conventional banks and Islamic banks is basically the same, but the difference between the two is the existence of Shariah compliance and the existence of the Sharia Supervisory Board (DPS). Islamic banks managed and owned by human resources who have integrity (good morals) and professionals, will encourage the implementation of the principles of good governance (Good Corporate Governance).
\end{abstract}

Keywords: Good Corporate Governance, Implementation, Syaria Banking.

\begin{abstract}
Abstrak
Sebagai salah satu entitas bisnis yang berada di bawah payung negara kesatuan Indonesia, bank syariah pun dituntut untuk menerapkan Good Corporate Governance yang untuk selanjutnya akan disingkat dengan GCG. Penerapan GCG di bank syariah menjadi penting mengingat bank syariah merupakan bank yang menggunakan prinsip profit sharing. GCG menjadi syarat bagi bank syariah untuk berkembang dengan baik dan sehat. Penerapan GCG yang baik mengacu pada lima prinsip yaitu akuntabilitas, transparansi, independensi, tanggung jawab, dan kewajaran. Konsep Good Corporate Governance antara bank. konvensional dengan bank syariah pada dasarnya adalah sama, namun yang menjadi pembeda diantara keduanya ialah adanya syariah compliance dan adanya Dewan Pengawas Syariah (DPS). Bank syariah yang dikelola dan dimiliki oleh sumber daya manusia yang mempunyai integrity (moral yang baik) dan profesional, akan mendorong pelaksanaan prinsip tata kelola yang baik (Good Corporate Governance).
\end{abstract}

Kata Kunci: Good Corporate Governance, Penerapan, Perbankan Syariah

\section{PENDAHULUAN}

Perkembangan institusi keuangan Islam khususnya bank syariah mulai meningkat dari tahun ke tahun. Bank syariah mulai berkembang di Indonesia pasca disetujuinya UU No. 10 Tahun 1998, yang mengatur dengan rinci landasan hukum serta jenis-jenis usaha yang dapat dioperasikan dan diimplementasikan oleh bank syariah. Hal lain yang memicu tumbuhnya bank syariah adalah Fatwa MUI tentang haramnya bunga bank. Dengan adanya fatwa tersebut jelas memperkuat posisi bank syariah sebagai satu-satunya alternatif bagi kaum muslimin untuk menitipkan uangnya. Hal ini dikarenakan pandangan masyarakat yang menganggap bahwa bank syariah adalah lembaga keuangan yang telah bebas dari praktik riba. 
Sebagai salah satu entitas bisnis yang berada di bawah payung negara kesatuan Indonesia, bank syariah pun dituntut untuk menerapkan Good Corporate Governance yang untuk selanjutnya akan disingkat dengan GCG. Penerapan GCG di bank syariah menjadi penting mengingat bank syariah merupakan bank yang menggunakan prinsip profit sharing (keuntungan dibagi bersama antara bank dan nasabah) (Chapra, 2002). Pedoman GCG yang telah dikeluarkan oleh Komite Nasional Kebijakan Governance (KNKCG) mengikat seluruh entitas bisnis, baik yang konvensional maupun syariah. Hal ini dilakukan sebagai upaya pemerintah untuk menciptakan iklim dunia usaha yang sehat.

Definisi GCG menurut Bank Dunia adalah aturan, standar dan organisasi di bidang ekonomi yang mengatur perilaku pemilik perusahaan, direktur dan manajer serta perincian dan penjabaran tugas dan wewenang serta pertanggungjawabannya kepada investor (pemegang saham dan kreditur). Tujuan utama dari GCG adalah untuk menciptakan sistem pengendaliaan dan keseimbangan (check and balances) untuk mencegah penyalahgunaan dari sumber daya perusahaan dan tetap mendorong terjadinya pertumbuhan perusahaan.

Namun demikian, beberapa permasalahan muncul ketika pedoman GCG konvensional dipandang tidak cukup mengakomodasi kebutuhan tata kelola perusahaan dengan prinsip syariah khususnya bank syariah. Ada dua alasan utama mengapa pedoman GCG konvensional dipandang kurang mengakomodasi kebutuhan corporate governance pada institusi keuangan Islam. Pertama, nilai-nilai Islam yang melekat pada institusi keuangan Islam belum diakomodasi oleh pedoman GCG konvensional. Kewajiban institusi keuangan Islam untuk taat pada kaidah-kaidah syariah dalam setiap praktiknya menjadi hal yang seharusnya lebih diutamakan daripada unsur-unsur lainnya.

Kedua, secara teoritis institusi keuangan Islam dipandang lebih pas bila menggunakan konsep shariah enterprise theory, yang membuat struktur dan orientasi perusahaannya berbeda dengan perusahaan konvensional yang menganut konsep entity theory. Dengan dianutnya konsep shariah enterprise theory, orientasi institusi keuangan Islam bukan hanya sekadar untuk mencari keuntungan semata, namun lebih menekankan pada zakat sebagai alat pendistribusian kesejahteraan. Di samping itu, diterapkannya GCG pada institusi keuangan Islam adalah sebuah keniscayaan yang tak terbantahkan. Bahkan menurut Agustianto (2008), bank-bank syariah seharusnya tampil sebagai pionir terdepan dalam pengimplementasian GCG tersebut. Hal ini dikarenakan institusi keuangan Islam memiliki tanggung jawab vertikal kepada Allah swt disamping bertanggung jawab kepada stakeholders.

Agar penerapan GCG lebih efektif di perbankan syariah, Bank Indonesia telah mengeluarkan Peraturan Bank Indonesia (PBI) Nomor 11/33/PBI/2009 yang selanjutnya dilengkapi dengan Surat Edaran Bank Indonesia (SEBI) tentang Pelaksanaan GCG di Bank Umum Syariah (BUS) dan Unit Usaha Syariah (UUS). Sejak dikeluarkannya PBI tersebut, bank syariah berkewajiban menerapkan GCG dan melakukan self assessment serta kemudian membuat laporan tentang penerapan GCG dalam laporan tahunannya (Faozan, 2013). Bank syariah harus memastikan bahwa prinsip-prinsip GCG tersebut telah diterapkan pada setiap aspek bisnis dan di seluruh jajarannya. Penerapan prinsip-prinsip GCG tersebut diperlukan untuk mencapai kesinambungan usaha (sustainability) bank syariah dengan tetap memperhatikan kepentingan para pemegang saham, nasabah serta pemangku kepentingan lainnya. 


\section{PRINSIP DASAR GOOD CORPORATE GOVERNANCE PADA PERBANKAN SYARIAH}

Sebagaimana dijelaskan dalam Peraturan Bank Indonesia No. 11/33/PBI/2009 bahwa prinsip-prinsip dalam GCG harus menerapkan prinsip keterbukaan (transparency), akuntabilitas (accountability), pertanggungjawaban (responsibility), profesional (professional), dan kewajaran (fairness). Selain itu Prinsip dasar pelaksanaan GCG ini juga dijelaskan dalam pedoman Good Governance Bisnis Syariah (GGBS). Prinsip ini dapat dijelaskan sebagai berikut:

\section{Keterbukaan (transparency)}

Keterbukaan (transparency) mengandung unsur pengungkapan (disclosure) dan penyediaan informasi yang memadai dan mudah diakses oleh pemangku kepentingan. Transparansi diperlukan agar pelaku bisnis syariah menjalankan bisnis secara objektif dan sehat. Pelaku bisnis syariah harus mengambil inisiatif untuk mengungkapkan tidak hanya masalah yang disyaratkan oleh peraturan perundangan, tetapi juga hal yang penting untuk pengambilan keputusan yang sesuai dengan ketentuan syariah.

\section{Akuntabilitas (accountability)}

Akuntabilitas (accountability) mengandung unsur kejelasan fungsi dalam organisasi dan cara mempertanggungjawabkannya. Pelaku bisnis syariah harus dapat mempertanggungjawabkan kinerjanya secara transparan dan wajar. Untuk itu bisnis syariah harus dikelola secara benar, terukur dan sesuai dengan kepentingan pelaku bisnis syariah dengan tetap memperhitungkan pemangku kepentingan dan masyarakat pada umumnya. Akuntabilitas merupakan prasyarat yang diperlukan untuk mencapai kinerja yang berkesinambungan.

\section{Pertanggungjawaban (responsibility)}

Dalam hubungan dengan asas responsibilitas (responsibility), pelaku bisnis syariah harus mematuhi peraturan perundangan dan ketentuan bisnis syariah, serta melaksanakan tanggung-jawab terhadap masyarakat dan lingkungan. Dengan pertanggungjawaban ini maka entitas bisnis syariah dapat terpelihara kesinambungannya dalam jangka panjang dan mendapat pengakuan sebagai pelaku bisnis yang baik (good corporate citizen).

Profesional (professional)

Professional yaitu memiliki kompetensi, mampu bertindak obyektif dan bebas dari pengaruh/tekanan dari pihak manapun (independen) serta memiliki komitmen yang tinggi untuk mengembangkan bank syariah. Dalam hubungan dengan asas independensi (independency), bisnis syariah harus dikelola secara independen sehingga masing-masing pihak tidak boleh saling mendominasi dan tidak dapat diintervensi oleh pihak manapun. Independensi terkait dengan konsistensi atau sikap istiqomah yaitu tetap berpegang teguh pada kebenaran meskipun harus menghadapi risiko.

Kewajaran (fairness)

Kewajaran (fairness) mengandung unsur kesamaan perlakuan dan kesempatan. Fairness atau kewajaran merupakan salah satu manifestasi adil dalam dunia bisnis. Setiap keputusan bisnis, baik dalan skala individu maupun lembaga, hendaklan dilakukan sesuai kewajaran dan kesetaraan sesuai dengan apa yang biasa berlaku, dan tidak diputuskan berdasar suka atau tidak suka. Pada dasarnya, semua keputusan bisnis akan mendapatkan hasil yang seimbang dengan apa yang dilakukan oleh setiap entitas bisnis, baik di dunia maupun di akhirat. Dalam melaksanakan kegiatannya, Pelaku bisnis syariah harus senantiasa memperhatikan kepentingan semua pemangku kepentingan, berdasarkan asas kewajaran dan kesetaraan. 


\section{PERBEDAAN GOOD CORPORATE GOVERNANCE PADA BANK SYARIAH DENGAN BANK KONVENSIONAL}

Menurut Pasal 2 Undang-Undang Nomor 21 Tahun 2008 tentang Bank Syariah (UU No. 21/2008), perbankan syariah dalam melakukan kegiatan usahanya berasaskan prinsip syariah, demokrasi ekonomi, dan prinsip kehati-hatian. Dalam penjelasan Pasal 2 dikemukakan kegiatan usaha yang berasaskan berikut ini (Sutedi, 2009):

1. Prinsip syariah;

2. Demokrasi ekonomi yakni kegiatan ekonomi syariah yang mengandung nilai keadilan, kebersamaan, pemerataan, dan kemanfaatan; dan

3. Prinsip kehati-hatian adalah pedoman pengelolaan bank yang wajib dianut guna mewujudkan perbankan yang sehat, kuat dan efisien, sesuai dengan ketentuan peraturan perundang-undangan.

Lebih lanjut prinsip syariah dijelaskan sebagai kegiatan usaha yang tidak mengandung unsur (Maradita, 2014):

1. Riba, yaitu penambahan pendapatan secara tidak sah (bathil) antara lain dalam transaksi pertukaran barang sejenis yang tidak sama kualitas, kuantitas, dan waktu penyerahan (fadhl), atau dalam transaksi pinjam-meminjam yang mempersyaratkan nasabah penerima fasilitas mengembalikan dana yang diterima melebihi pokok pinjaman karena berjalannya waktu (nasi'ab);

2. Maisir, yaitu transaksi yang digantungkan kepada suatu keadaan yang tidak pasti dan bersifat untung-untungan;

3. Gharar, yaitu transaksi yang objeknya tidak jelas, tidak dimiliki, tidak diketahui keberadaannya, atau tidak dapat diserahkan pada saat transaksi dilakukan, kecuali diatur lain dalam syariah;

4. Haram, yaitu transaksi yang objeknya dilarang dalam syariah;
5. Zalim, yaitu transaksi yang menimbulkan ketidakadilan bagi pihak lainnya.

Berdasarkan prinsip-prinsip diatas maka perbedaan GCG syariah dan konvensional terletak pada syariah compliance yaitu ketaatan bank syariah terhadap prinsip-prinsip syariah. Makna kepatuhan syariah dalam bank syariah secara konsep sesungguhnya adalah penerapan prinsip-prinsip Islam, syariah dan tradisinya kedalam transaksi keuangan dan perbankan serta bisnis lain yang terkait secara konsisten dan menjadikan syariah sebagai kerangka kerja bagi sistem dan keuangan bank syariah dalam alokasi sumber daya, manajemen, produksi, aktivitas pasar modal, dan distribusi kekayaan (Sutedi, 2009). Jaminan kepatuhan syariah (shari'a compliance assurance) atas keseluruhan aktivitas bank syariah merupakan hal yang sangat penting bagi nasabah dan masyarakat.

Menurut Sutedi (2009) ada beberapa indikator yang dapat digunakan sebagai ukuran secara kualitatif untuk menilai kepatuhan syariah dalam bank syariah, antara lain sebagai berikut:

1. Akad atau kontrak yang digunakan untuk penyaluran dana sesuai dengan prinsip-prinsip dan aturan syariah yang berlaku;

2. Dana zakat dihitung dan dibayar serta dikelola sesuai dengan aturan dan prinsip-prinsip syariah;

3. Seluruh transaksi dan aktivitas ekonomi dilaporkan secara wajar sesuai dengan standar akuntansi syariah yang berlaku;

4. Lingkungan kerja dan corporate culture sesuai dengan syariah;

5. Bisnis dan usaha yang dibiayai tidak bertentangan dengan syariah;

6. Terdapat dewan pengawas syariah sebagai pengarah syariah atas keseluruhan aktivitas operasional bank syariah;

7. Sumber dana berasal dari sumber dana yang sah dan halal menurut syariah.

Selain kepatuhan pada syariah, dilihat dari struktur organisasi bank syariah, unsur yang 
membedakan dengan bank konvensional adalah adanya keharusan bank syariah memiliki Dewan Pengawas Syariah (DPS). DPS ini bertugas untuk mengawasi operasional bank dan produkproduk bank syariah agar sesuai dengan prinsip syariah. Hal ini karena transaksi-transaksi yang berlaku dalam bank syariah sangat khusus jika dibandingkan bank konvensional. DPS harus membuat pernyataan secara berkala (biasanya tiap tahun) bahwa bank yang diawasinya telah berjalan sesuai dengan ketentuan syariah. Pernyataan ini dimuat dalam laporan tahunan (annual report) bank bersangkutan. Tugas lain DPS adalah meneliti dan membuat rekomendasi produk baru dari bank yang diawasinya. Dengan demikian, DPS bertindak sebagai penyaring pertama sebelum suatu produk diteliti kembali dan difatwakan oleh Dewan Syariah Nasional (DSN).

Menurut Antonio (2001) selain DPS, Majelis Ulama Indonesia memiliki Dewan Syariah Nasional (DSN), fungsi utama DSN adalah mengawasi produk-produk lembaga keuangan syariah agar sesuai dengan syariah Islam. Untuk keperluan pengawasan tersebut, DSN membuat garis panduan produk syariah yang diambil dari sumber-sumber hukum Islam. Fungsi lain dari DSN adalah meneliti dan memberi fatwa bagi produk-produk yang dikembangkan oleh lembaga keuangan syariah. Panduan DSN ini menjadi pedoman bagi DPS untuk melakukan pengawasan terhadap produk-produk bank. Hal-hal tersebut diatas inilah yang tidak dimiliki oleh perbankan konvensional sehingga menjadi pembeda dengan bank syariah.

Untuk melengkapi PBI-2009 dalam mengimplementasikan GCG di Perbankan Syariah, KNKG (Komite Nasional Kebijakan Governance) membentuk Tim Kerja Penyusunan Pedoman Umum Good Governance Bisnis Syariah (GGBS) dengan keanggotaan yang terdiri dari berbagai pakar terkait bersama-sama dengan sejumlah institusi (Masyarakat Ekonomi Syariah, Bank
Indonesia, Dewan Syariah Nasional MUI dan sebagainya) menyusun konsep Pedoman tersebut. Pada 3 November 2011, KNKG meluncurkan Pedoman GGBS. Dengan diluncurkannya GGBS, maka pedoman ini akan menjadi pedoman pelaksanaan tata kelola entitas bisnis syariah khususnya bank syariah di Indonesia, antara lain:

1. Kesadaran dan komitmen untuk meningkatkan ketakwaan, manfaat, dan keberkahan dalam berbisnis.

2. Pengambilan keputusan bisnis didasarkan pada nilai akhlak islam dan kepatuhan terhadap peraturan perundang-undangan;

3. Kesinambungan entitas bisnis syariah melalui pengelolaan yang didasarkan pada praktikpraktik bisnis dengan karakter dan sifat-sifat Rasulullah SAW.

4. Pemberdayaan fungsi dan kemandirian masingmasing organ kelembagaan dari entitas bisnis syariah yang bersangkutan.

5. Kesadaran dan tanggung jawab sosial pelaku bisnis syariah terhadap kemaslahatan ummat manusia dan kelestarian lingkungan.

6. Optimalisasi nilai bisnis syariah bagi pemangku kepentingan.

7. Pengembangan ekonomi Islam secara kuantitas maupun kualitas serta kemanfaatan yang universal.

Tujuan di atas menunjukkan perbedaan antara GCG konvensional dan GGBS. Selain itu, letak perbedaan lainnya terletak pada prinsip dasar GGBS yang berorientasi pada spiritual dan penciptaan pra kondisi operasional.

\section{PERAN DEWAN PENGAWAS SYARIAH DALAM PENERAPAN PRINSIP ISLAMIC CORPORATE GOVERNANVE}

Bank syariah harus menjalankan fungsinya dengan baik sesuai dengan ketentuan perbankan yang berlaku dan juga sesuai pula dengan prinsip syariah. Untuk menjamin terlaksananya prinsip syariah, dalam aktifitas perbankan syariah terdapat salah 
satu pihak terafiliasi yaitu Dewan Pengawas Syariah (DPS) yang memberikan jasanya kepada bank syariah. Dewan inilah sebagai pihak yang bertanggungjawab atas informasi tentang kepatuhan pengelola bank akan prinsip syariah.

Menurut Arifin (2005), DPS adalah badan independen yang ditempatkan oleh Dewan Syariah Nasional (DSN) yang berada pada suatu bank syariah. Anggota DPS terdiri dari pakar di bidang syariah muamalah yang juga mengetahui pengetahuan umum di bidang perbankan. Dalam melaksanakan tugasnya, DPS wajib mengikuti fatwa DSN mengenai kesesuain produk dan jasa bank dengan ketentuan dan prinsip syariah. Tugas utamanya adalah mengawasi kegiatan usaha lembaga keuangan syariah agar sesuai dengan ketentuan dan prinsip syariah yang telah difatwakan oleh DSN.

AAOIFI dalam Governance Standard for Islamic Finacial Institutions (GSIFI) menjelaskan bahwa peran DPS adalah directing, reviewing and supervising the activities of Islamic Financial Institution in orderto ensure that they are in compliance with Islamic shari'a rules and principles. Artinya, peran DPS yakni mengarahkan, menilai,dan mengawasi seluruh aktivitas institusi keuangan Islam untuk memastikan aktivitasnya sesuai prinsip dan aturan syariah.Dengan demikian, menurut AAOIFI ada tiga peran DPS di lembaga keuangan syariah, yaitu melakukan penilaian, pengarahan dan pengawasan atas aktivitas bank syariah agar sesuai dengan aturan dan prinsip syariah.

Selain tiga peran di atas, DSN MUI menambahkan satu peran DPS yaitu melakukan sosialisasi dan edukasi kepada masyarakat tentang bank syariah melalui media-media yang sudah berjalan di masyarakat, seperti khutbah, majelis ta'lim, pengajian-pengajian. Atau, lebih tepatnya peran DPS menurut DSN MUI tersebut adalah sebagai pihak yang juga ikut memasarkan (marketing) bank syariah kepada masyarakat.
Memperhatikan kepada peran DPS menurut AAOIFI dan DSN-MUI, maka peran DPS dalam implentasi prinsip-prinsip GCG di bank syariah adalah sebagai berikut:

1. Directing yaitu memberikan pengarahan, pemikiran, saran dan nasehat kepada direksi bank syariah mengenai hal-hal yang berkaitan dengan aspek syariah.

2. Reviewing yaitu mencermati, memeriksa, mengkaji dan menilai implementasi fatwa DSN pada operasional bank syariah.

3. Supervising yaitu melaksanakan tugas pengawasan baik secara aktif maupun secara pasif atas implementasi fatwa DSN pada operasional bank syariah.

4. Marketing yaitu melakukan sosialisasi dan edukasi kepada masyarakat tentang bank syariah melalui media-media yang sudah berjalan di masyarakat, seperti khutbah, majelis ta'lim, pengajian-pengajian.

DPS dalam struktur bank syariah berada setingkat dengan komisaris sebagai pengawas direksi. Jika komisaris adalah sebagai pengawas kinerja manajemen bank, maka DPS adalah pengawas menejemen bank yang berkaitan dengan operasionalnya sehari-hari agar selalu sesuai dengan prinsip syariah yang difatwakan oleh Dewan Syariah Nasional (DSN). Keberadaan DPS di bank syariah sangat penting sebagai pihak yang berperan di dalam mengawasi operasionalnya agar benar-benar berjalan di atas rel syariah. DPS diharapkan dapat menjamin dan memastikan bahwa suatu bank syariah dalam semua kegiatannya telah menerapkan prinsip syariah.

Dalam pelaksanaan tugasnya, diatur dalam pasal 46 PBI-2009. Berikut tugas dan tanggung jawab Dewan Pengawas Syariah:

1. Dewan Pengawas Syariah wajib melaksanakan tugas dan tanggung jawab sesuai dengan prinsip-prinsip GCG.

2. Tugas dan tanggung jawab Dewan Pengawas Syariah adalah memberikan nasihat dan saran 
kepada Direksi serta mengawasi kegiatan Bank agar sesuai dengan Prinsip Syariah.

3. Pelaksanaan tugas dan tanggung jawab Dewan Pengawas Syariah meliputi: menilai dan memastikan pemenuhan Prinsip Syariah atas pedoman operasional dan produk yang dikeluarkan Bank, mengawasi proses pengembangan produk baru Bank agar sesuai dengan fatwa Dewan Syariah Nasional Majelis Ulama Indonesia, meminta fatwa kepada Dewan Syariah Nasional - Majelis Ulama Indonesia untuk produk baru Bank yang belum ada fatwanya, melakukan review secara berkala atas pemenuhan Prinsip Syariah terhadap mekanisme penghimpunan dana dan penyaluran dana serta pelayanan jasa Bank, dan meminta data dan informasi terkait dengan aspek syariah dari satuan kerja Bank dalam rangka pelaksanaan tugasnya.

4. Dewan Pengawas Syariah wajib menyampaikan Laporan Hasil Pengawasan Dewan Pengawas Syariah secara semesteran yang disampaikan kepada Bank Indonesia paling lambat 2 (dua) bulan setelah periode semester dimaksud berakhir.

\section{PENERAPAN PRINSIP ISLAMIC CORPORATE GOVERNANVE DI PERBANKAN SYARIAH}

Secara yuridis Bank Syariah bertanggung jawab kepada banyak pihak (stakeholders), yaitu nasabah penabung, pemegang saham, investor obligasi, bank koresponden, regulator, pegawai, pemasok, masyarakat, dan lingkungan. Penerapan GCG merupakan wujud penanggung-jawaban kepada masyarakat bahwa bank syari'ah dikelola dengan baik, profesional, dan hati-hati dengan tetap berupaya meningkatkan nilai pemegang saham tanpa mengabaikan kepentingan stakeholders lainnya.

Pelaksanaan good corporate governance (GCG) di bank syariah merupakan bagian tak terpisahkan dari spirit bank syariah yang intinya adalah semangat tanggung jawab, kewajiban, keterbukaan dan keadilan melalui pengabdian serta ketundukan kepada Allah SWT dan penghargaan melalui pemerataan kemampuan, pengetahuan, informasi dan penghargaan. Semangat inilah yang menjadi dasar bagi tata kelola usaha/bisnis dan kode etik dalam bank syariah, termasuk dalam memberikan pembiayaan untuk bisnis syariah.

Pelaksanaan Good Corporate Governance (GCG), juga sangat diperlukan untuk membangun kepercayaan masyarakat dan dunia internasional sebagai syarat mutlak bagi dunia perbankan untuk berkembang dengan baik dan sehat. Oleh karena itu, Bank for International Sattlement (BIS) sebagai lembaga yang mengkaji terus menerus prinsip kehati-hatian yang harus dianut oleh perbankan, telah pula mengeluarkan Pedoman Pelaksanaan GCG bagi dunia perbankan secara internasional. Pedoman serupa dikeluarkan pula oleh lembagalembaga internasional lainnya. Indonesia juga membentuk Komite Nasional Kebijakan Corporete Governance (KNKCG), yang telah menerbitkan Pedoman Good Corporate Governance Perbankan Indonesia (Indonesian Banking Sector Code) sebagai pelengkap dan bagian tak terpisahkan dari Pedoman Umum GCG.

Dalam Undang-Undang Nomor 21 Tahun 2008 tentang Perbankan Syari'ah, tata kelola Perbankan Syari'ah diatur dalam Pasal 34 ayat (1) "Bank Syari'ah dan Unit Usaha Syari'ah (UUS) wajib menerapkan tata kelola yang baik yang mencakup prinsip transparansi, akuntabilitas, pertanggungjawaban, profesional dan kewajaran dalam menjalankan kegiatan usahanya”.

Penerapan prinsip transparansi dalam perbankan syari'ah terlihat dalam Pasal 35 ayat (5) Undang-Undang Perbankan Syari'ah, yang menetapkan bahwa "bank syariah wajib mengumumkan neraca dan laporan laba rugi kepada publik dalam waktu dan bentuk yang ditentukan oleh Bank Indonesia”. Juga Pasal 39, yang menyatakan bahwa "Bank Syariah wajib dan 
Unit Usaha Syariah (UUS) wajib menjelaskan kepada nasabah mengenai kemungkinan timbulnya risiko kerugian sehubungan dengan transaksi nasabah yang dliakukan melalui Bank Syari'ah dan/atau Unit Usaha Syariah."

Kewajiban ini terkait dengan kepentingan nasabah penyimpanan dana dan nasabah investor pada bank syariah agar nasabah penyimpan dana dan nasabah investor mengetahui keadaan keuangan bank syari'ah dari waktu ke waktu. Pelaksanaan kewajiban untuk mengumumkan neraca dan perhitungan laba rugi tersebut secara tertib oleh setiap bank syariah sangat diperlukan oleh masyarakat mengingat tingkat kesehatan masing- masing bank syari'ah sesuai dengan penilaian Bank Indonesia bersifat rahasia tidak boleh diketahui oleh umum. Prinsip transparansi bagi nasabah penyimpan dana dan nasabah investor sangat penting sekali, terutama deposito milik nasabah investor yang berdasarkan pada mudharabah. Hal ini dikarenakan pada mudharabah tidak diketahui berapa keuntungan pasti yang akan diterima, yang diketahui hanyalah nisbah bagi hasil. Berbeda dengan simpanan deposito di bank konvensional yang sudah tahu berapa jumlah keuntungan yang akan diterima.

Menurut M. Umer Chapra dan Habib Ahmed bahwa penerapan GCG yang efektif sangat dibutuhkan untuk memenuhi kepentingan semua stakeholder secara adil. Demikian juga yang dikemukakan oleh Suhaimi Moh Yusuf yang dikutip oleh Mal An Abdullah bahwa tujuan GCG dalam perbankan syariah adalah untuk menegakkan keadilan, kejujuran dan perlindungan terhadap kebutuhan manusia sesuai dengan maqashid al syariah.

Bank syariah sebagai lembaga intermediasi, fungsi sosial, mitra nasabah dan lembaga amanah dalam melaksanakan kegiatan usahanya bank syariah harus menganut prinsip keterbukaan (transparency), yang memiliki ukuran kinerja dari semua jajaran bank syariah berdasarkan ukuran- ukuran yang konsisten dengan corporate values, sasaran usaha dan strategi bank sebagai pecerminan akuntabilitas bank (acountability) berpegang pada prudential banking practices dan menjamin dilaksanakannya ketentuan yang berlaku sebagai wujud tanggung jawab bank syariah (responsibility), obyektif dan bebas dari tekanan pihak manapun dalam pengambilan keputusan (independency), serta senantiasa memperhatikan kepentingan seluruh stakeholder berdasarkan asas kesetaraan dan kewajaran (fairness).

Bank syariah, dalam pelaksanaan GCG harus diwujudkan dalam :

1. Pelaksanaan tugas dan tanggungjawab Dewan Komisaris dan Direksi ;

2. Kelengkapan dan pelaksanaan tugas komitekomite dan satuan kerja yang menjalankan fungsi pengendalian intern bank ;

3. Penerapan fungsi kepatuhan, auditor internal dan auditor eksternal;

4. Penerapan manajemen risiko, termasuk sistem pengendalian intern;

5. Penyediaan dana kepada pihak terkait dan penyedian dana besar;

6. Rencana strategis bank;

7. Transparansi kondisi keuangan dan non keuangan bank.

Dalam rangka menerapkan kelima prinsip dasar GCG tersebut, bank selain wajib berpedoman pada berbagai ketentuan dan persyaratan yang terkait dengan pelaksanaan Good Corporate Governance, juga harus memenuhi shariah compliance (kepatuhan syariah). Ketidaksesuaian corporate governance dengan prinsip syariah/kepatuhan syariah akan berpotensi menimbulkan berbagai risiko terutama risiko reputasi bagi industri perbankan syariah.

Kepatuhan syariah merupakan manifestasi pemenuhan seluruh prinsip syariah dalam lembaga yang memiliki wujud karakteristik, integritas dan kredibilitas di bank syariah. Dimana budaya kepatuhan tersebut adalah nilai, perilaku dan 
tindakan yang mendukung terciptanya kepatuhan bank syariah terhadap seluruh ketentuan Bank Indonesia. Elemen yang memiliki otoritas dan wewenang dalam melakukan pengawasan terhadap kepatuhan syariah adalah Dewan Pengawas Syariah (DPS). Dewan Pengawas Syariah melengkapi tugas pengawasan yang diberikan oleh komisaris, dimana kepatuhan syariah semakin penting untuk dilakukan dikarenakan adanya permintaan dari nasabah agar bersifat inovatif dan berorientasi bisnis dalam menawarkan instrumen dan produk baru serta untuk memastikan kepatuhan terhadap hukum Islam.

Untuk meningkatkan kepatuhan terhadap prinsip syariah oleh bank, paling tidak terdapat dua langkah penting yang perlu ditempuh, yaitu:

1. Perlunya mengefektifkan aturan dan mekanisme pengakuan dari otoritas fatwa dalam hal ini DSN-MUI dalam hal menentukan kehalalan atau kesesuaian produk dan jasa keuangan bank dengan prinsip syariah.

2. Perlunya mengefektifkan sistem pengawasan yang memantau transaksi keuangan bank sesuai dengan fatwa yang dikeluarkan oleh otoritas fatwa perbankan. Terkait dengan hal ini permasalahan yang sering muncul adalah masih minimnya ahli yang memiliki pemahaman ilmu fiqh dan syariah serta sekaligus memiliki pengetahuan perbankan yang memadai.

\section{KESIMPULAN}

GCG merupakan suatu sistem pengelolaan perbankan yang dirancang untuk meningkatkan kinerja bank, melindungi kepentingan stakeholders dan meningkatkan kepatuhan terhadap peraturan perundang-undangan serta nilai-nilai etika yang berlaku secara umum. Oleh sebab itu, untuk membangun kepercayaan masyarakat kepada bank syariah dan menjamin kepatuhan terhadap prinsip syariah, diperlukan pelaksanaan GCG sebagai syarat bagi bank syariah untuk berkembang dengan baik dan sehat.
Konsep Good Corporate Governance antara bank konvensional dengan bank syariah pada dasarnya adalah sama, namun yang menjadi pembeda diantara keduanya ialah adanya syariah compliance yaitu kepatuhan pada syariah, kemudian adanya Dewan Pengawas Syariah (DPS) yang bertugas meneliti dan membuat rekomendasi produk baru dari bank yang diawasinya serta melakukan pengawasan terhadap bank syariah bahwa kegiatan usaha yang dilakukannya mematuhi prinsip syariah sebagaimana telah ditentukan oleh fatwa dan syariah Islam. Serta adanya Dewan Syariah Nasional yang fungsi utamanya adalah mengawasi produk produk lembaga keuangan syariah agar sesuai dengan syariah Islam.

Bank syariah yang dikelola dan dimiliki oleh sumber daya manusia yang mempunyai integrity (moral yang baik) dan profesional, akan mendorong pelaksanaan prinsip tata kelola yang baik (Good Corporate Governance). Oleh karena itu bank syari'ah harus dimiliki dan dikelola oleh pihak- pihak yang mempunyai integritas yang tinggi mempunyai kompetensi yang memadai, serta memiliki kelayakan keuangan dan/atau reputasi keuangan yang baik.

\section{DAFTAR KEPUSTAKAAN}

AAOIFI. (1999). Accounting and Auditing and Governance Standard for Islamic Financial Institutions. Manama, Bahrain: AAOIFI.

Agustianto. (2008). Menyoal Office Channeling Bank Syariah. Artikel Perbankan Syariah.

Antonio, M. S. (2001). Bank Syariah: Dari Teori ke Praktik. Jakarta: Gema Insani Press.

Arifin, Z. (2005). Dasar-Dasar Manajemen Bank Syariah. Jakarta: Pustaka Alfabet.

Asrori. (2014). Implementasi Islamic Corporate Governance dan Implikasinya Terhadap Kinerja Bank Syariah. Jurnal Dinamika Akuntansi Vol. 6, No. 1, Maret 2014, pp. 90102.

Bank Indonesia. (2009). Peraturan Bank Indonesia Nomor 11/33/PBI/2009 Tentang Pelaksanaan 
Good Corporate Governance bagi Bank Umum Syariah dan Unit Usaha Syariah.

Binhadi. (3 November 2011). Pokok-Pokok Pedoman GGBS dan Urgensi Kehadiran Pedoman GGBS. Presentasi Pada Seminar Peluncuran Pedoman Umum Good Governance Bisnis Syariah.

Chapra, M. U., \& Ahmed, H. (2002). Islamic Governance In Islamic Financial Institutions. Jeddah: Islamic Research and Islamic Institute, Islamic Development Bank.

Faozan, A. (2013). Implementasi Good Corporate Governance dan Peran Dewan Pengawas Syariah di Bank Syariah. Jurnal Ekonomi Islam Volume VII, No. 1, Juli 2013.

Komite Nasional Kebijakan Governance. (2011). Pedoman Umum Good Governance Bisnis Syariah (GGBS).

Maradita, A. (2014). Karakteristik Good Corporate Governance Pada Bank Syariah dan Bank Konvensional. Yuridika : Volume 29 No. 2, Mei-Agustus 2014.

Sutedi, A. (2009). Perbankan Syariab: Tinjauan dan Beberapa Segi Hukum. Bogor: Ghalia Indonesia.

Undang-Undang Republik Indonesia Nomor 21 Tabun 2008 Tentang Perbankan Syariah. 